\title{
HIGH D-DIMER VALUES AND POST-DISCHARGE ACUTE PULMONARY EMBOLISM IN YOUNG PATIENTS WITH COVID-19: A CASE SERIES
}

\author{
Calin Pop,${ }^{1,2}$ Ionuț Ferenț ${ }^{1}$ \\ ${ }^{1}$ Emergency Clinical County Hospital of Baia Mare, Baia Mare, Romania \\ 2 "Vasile Goldis" University, Faculty of Medicine Arad, Arad, Romania
}

Primljen/Received 22. 02. 2021. god.

Prihvaćen/Accepted 10. 04. 2021. god.

Abstract: Introduction: The coronavirus disease (COVID-19), caused by severe acute respiratory syndrome coronavirus 2 (SARS-CoV-2), is associated with an inflammatory and prothrombotic state that increases the risk of thromboembolic events. High levels of D-dimer are associated with the severity of the disease and acute pulmonary embolism (PE) is the most common thrombotic complication.

Material and methods: We analyzed a series of four cases of COVID-19 in young patients (under 45 years) who developed PE with a delay of two to four weeks after hospital discharge.

Results: These patients had elevated D-dimer (at least 10 times the upper limit of normal) at the initial admission and at the time of the PE diagnostic, while other parameters which involved inflammation and coagulation (C-reactive protein - CRP; lactate dehydrogenase - LDH; fibrinogen; international normalized ratio INR) were normal. There were no pre-existing risk factors for PE and all the patients were anticoagulated with prophylactic intermediate doses of enoxaparin.

Conclusions: PE is a complication of the COVID-19 disease which may occur later, especially in young patients with no other risk factors for the condition. The highly elevated levels of D-dimer at COVID-19 admission seem to be associated with the post-discharge apparition of PE. This data suggests the role of extended anticoagulation in selected COVID-19 patients and warrants further investigations.

Key words: D-dimer, COVID-19, young patients, pulmonary embolism, post-discharge.

\section{INTRODUCTION}

COVID-19, caused by the SARS-CoV-2 coronavirus, is an infectious disease that usually presents respiratory symptoms, predisposing patients to venous thromboembolic (VTE) complications (1). COVID-19 was associated with an inflammatory status, cytokine and chemokines secretion, endothelial injury, or coagulation abnormalities, with marked elevations seen in C-reactive protein (CRP), lactate dehydrogenase (LDH), ferritin, interleukin levels, and D-dimer (2). The result is the development of diffuse endothelial damage that predisposes to widespread thrombotic vascular lesions with microangiopathy, disrupted cell membranes, and new vessel growth (3). Patients with the elevation of D-dimer and fibrin degraded products have the worst prognosis $(\mathrm{p}=0.003$, for in-hospital death in the multivariable analysis) and higher severity of COVID-19 (4). The prevalence of pulmonary embolism (PE) was 15.8\% [95\% CI (6.0-28.8\%)] in a meta-analysis of nine studies which included 3066 patients with COVID-19 (5). PE was the most frequent thrombotic complication from the reported VTE events in hospitalized patients with COVID-19.

Our case series of four young COVID-19 patients (under 45 years) described the appearance of PE post-discharge. We present the most important clinical and laboratory findings with the aim that this data may help clinicians in identifying the patients at risk for late thromboembolic complications.

\section{MATERIAL AND METHODS}

Four patients with suspected COVID-19, initially hospitalized (diagnosis made via SARS-CoV-2 PCR in a certified laboratory) and discharged from two COVID-19 dedicated hospitals, were admitted to the Intensive Cardiac Care Unit of the Emergency County Hospital in Baia Mare because of the new onset of intense dyspnea. This hospital usually provides the treatment for suspected and proven PE patients in Baia Mare and Maramureș County. The Ethics Com- 
mittee of the Baia Mare Clinical County Emergency Hospital reviewed and approved the study (decision no. 34978/2020), which was done retrospectively with data collected from patients' records.

\section{RESULTS}

The clinical and laboratory characteristics of the patients are presented in Table 1.

Three of the four patients were male and all of them were between 31 and 45 years of age. None of them had medical antecedents, however, two were overweight with a BMI of 29 and 30. The symptoms were initially respiratory with cough and fever (37.5$38.5^{\circ} \mathrm{C}$ ); and one of the patients had arthralgia, myalgia, abdominal pain, diarrhea, and dyspnea. CT images displayed the presence of ground-glass opacities in all patients. Two of them had multi-affected lobes, one had two lobes, and the female patient had only one lobe affected. $\mathrm{SpO} 2$ was between $84-90 \%$ in two patients who had pressurized oxygen therapy for five days, $88-92 \%$ in one who had basal oxygen therapy

Table 1. Clinical and laboratory characteristics of PE patients

\begin{tabular}{|c|c|c|c|c|}
\hline Variables/ Patients & 1 & 2 & 3 & 4 \\
\hline Age & 45 & 42 & 35 & 29 \\
\hline Sex & male & male & female & male \\
\hline Medical history & none & none & none & none \\
\hline BMI kg/m² & 29 & 30 & 24.5 & 25 \\
\hline ECG & $\begin{array}{l}110 \mathrm{~b} / \mathrm{min}, \text { sinus } \\
\text { tachycardia }\end{array}$ & $\begin{array}{l}115 \mathrm{~b} / \mathrm{min} \text {, sinus } \\
\text { tachycardia }\end{array}$ & $\begin{array}{l}\text { incomplete right bundle } \\
\text { branch }\end{array}$ & $\begin{array}{l}\text { incomplete right bundle } \\
\text { branch }\end{array}$ \\
\hline PE symptoms & $\begin{array}{l}\text { acute dyspnea, right } \\
\text { thoracic pain, hemop- } \\
\text { tysis, }\end{array}$ & $\begin{array}{l}\text { left thoracic pain, } \\
\text { hypoxia } 90 \%\end{array}$ & acute dyspnoea & acute dyspnoea \\
\hline PE after ...days of Covid onset & 22 & 18 & 32 & 16 \\
\hline PE localisation at angio $\mathrm{CT}$ & $\begin{array}{c}\text { distal bilateral } \\
\text { segmental } \\
\text { and subsegmental }\end{array}$ & $\begin{array}{l}\text { distal left lower lobe } \\
\text { and central lobar right } \\
\text { superior }\end{array}$ & $\begin{array}{c}\text { distal bilateral } \\
\text { segmental }\end{array}$ & $\begin{array}{l}\text { distal unilateral lower } \\
\text { left lobe }\end{array}$ \\
\hline SARS-CoV-2 PCR at PE diagnosis & negative & negative & negative & positive \\
\hline $\begin{array}{l}\text { D-Dimer at Covid }-19 \text { diagnostic } \\
\text { RR: } 0.00-0.49 \mathrm{mg} / \mathrm{L} \text { FEU }\end{array}$ & 4.2 & 14.4 & 5.2 & 8.1 \\
\hline $\begin{array}{l}\text { D-Dimer, at PE diagnostic, } \\
\text { RR: } 0.00-0.49 \mathrm{mg} / \mathrm{L} \text { FEU }\end{array}$ & 4.8 & 16.8 & 14.3 & 13.4 \\
\hline $\begin{array}{l}\text { h-CRP (mg/dl) } \\
\text { RR: up to } 5 \mathrm{mg} / \mathrm{L}\end{array}$ & 12 & 25 & 10 & 4 \\
\hline $\begin{array}{l}\text { Fibrinogen }(\mathrm{g} / \mathrm{L}) \\
\text { RR: } 2.0 \text { to } 4.0 \mathrm{~g} / \mathrm{L}\end{array}$ & 4.3 & 5.2 & 4.6 & 3.7 \\
\hline $\begin{array}{l}\mathrm{LDH}(\mathrm{U} / \mathrm{l}) \\
\text { RR: } 100-250 \mathrm{IU} / \mathrm{L}\end{array}$ & 270 & 320 & 260 & 230 \\
\hline $\begin{array}{l}\text { Serum ferritin } \\
\text { RR; } 12-300 \mathrm{ng} / \mathrm{ml}\end{array}$ & 80 & 450 & - & - \\
\hline $\begin{array}{l}\text { BNP }(\mathrm{pg} / \mathrm{mL}) \\
\text { RR: }<100 \mathrm{pg} / \mathrm{ml}\end{array}$ & 485 & 630 & 350 & 180 \\
\hline $\begin{array}{l}\text { Haemoglobin }(\mathrm{g} / \mathrm{L}), \\
\text { RR: } 13-15 \mathrm{~g} / \mathrm{l}\end{array}$ & 15 & I4 & 12.5 & 15 \\
\hline $\begin{array}{l}\text { White-cell count (per mm) } \\
\text { RR: } 5000-10000\end{array}$ & 10300 & 11000 & 9600 & 9400 \\
\hline $\begin{array}{l}\text { Platelets (per mm) } \\
\text { RR: } 150000-450000\end{array}$ & 410000 & 520000 & 245000 & 375000 \\
\hline INR, RR: 0.8-1.1 & 1.1 & 1.05 & 1.2 & 1 \\
\hline Anticoagulation before PE onset & $\begin{array}{l}\text { Enoxaparin } 0.6 \mathrm{ml} \\
\text { once daily/ } 7 \text { days }\end{array}$ & $\begin{array}{l}\text { Enoxaparin } 0.6 \mathrm{ml} \\
\text { once daily/ } 7 \text { days }\end{array}$ & none & none \\
\hline PE treatment & $\begin{array}{l}\text { Enoxaparin therapeutic } \\
\text { doses, Dabigatran }\end{array}$ & $\begin{array}{l}\text { Enoxaparin therapeutic } \\
\text { doses, Dabigatran }\end{array}$ & $\begin{array}{c}\text { Enoxaparin therapeutic } \\
\text { doses, Dabigatran }\end{array}$ & $\begin{array}{c}\text { Enoxaparin therapeutic } \\
\text { doses, Apixaban }\end{array}$ \\
\hline
\end{tabular}

Legend: BMI - body mass index, ECG - electrocardiogram, bpm - beats per minute, PE - pulmonary embolism, FEU - Fibrinogen equivalent units, $\mathrm{CRP}-\mathrm{C}$ reactive protein, $\mathrm{LDH}$ - Lactate dehydrogenase thromboplastin time, $\mathrm{BNP}$ - brain natriuretic peptide, INR - international normalized ratio, LWMH - low weight molecular heparin, RR - reference range. 
for many days, and more than $92 \%$ in the female patient who had only intermittent oxygen therapy. The patients were initially managed in two COVID-19 dedicated hospitals and had anticoagulation therapy for VTE prevention (enoxaparin $0.6 \mathrm{ml}$ or $0.8 \mathrm{ml}$, or 1 $\mathrm{ml} \mathrm{SC}$, once a day-q.d) for 10 days. All of them were treated with antimicrobial therapy for secondary bacterial infection and with hydroxychloroquine $(400 \mathrm{mg}$ / day). They were discharged after a second negative SARS-CoV-2 PCR test made after 10 days of hospitalization. All the patients developed dyspnea of acute onset and/or chest pain 16 to 32 days after discharge, and they had to be hospitalized at the Emergency County Hospital Baia Mare under suspicion of PE. One of the four patients was, surprisingly, COVID-19 positive in the nasopharyngeal swab on the admission day. Biomarkers usually involved in inflammation were only slightly elevated in three of them, while the common coagulation test international normalized ratio (INR) was normal. The electrocardiogram presented sinus tachycardia (110-120 bpm) in two patients, while the other two had new development of an incomplete right bundle branch. None of them had signs of deep vein thrombosis at the venous duplex ultrasound scan (VDUS). The angio-CT scans revealed distal bilateral pulmonary emboli in three patients and smaller distal unilateral PE in one. There is no data for the D-dimer values on hospital discharge after COVID-19 treatment. The D-dimer were highly elevated (levels vary between 1.06 and $16.96 \mathrm{mg} / \mathrm{L}$, reference range $-\mathrm{RR}$ : 0.00-0.49 mg/L FEU) on the second hospital admittance, being the highest in patients with bilateral PE. All patients were started on anticoagulation therapy with enoxaparin SC at therapeutic doses, followed by oral administration of Dabigatran or Apixaban; all of them recovered well.

\section{DISCUSSION}

We report four cases of late PE in young patients (under 45 years), which appeared 16 to 32 days after discharge after being infected with the COVID-19 virus: the median time delay to the onset of symptoms was 20 days (interquartile range 4-12); the median age of patients was 38.5 years (interquartile range 9.5-6.5) - presented in Table 1 . A series of 15 case reports and small series (altogether 26 patients) were retrieved from a PubMed search for papers published up to November 31, 2020, concerning post-discharge PE events after mild COVID-19 cases. These cases reported the occurrence of late thromboembolic complications, especially in young patients (most of them under 50 years), with the absence or with various modalities of thromboprophylaxis during the COVID-19 course
(6-20). Patients under 65 years (younger cohort) had a significantly higher PE prevalence of $20.5 \%$, compared to the $14.3 \%(p<0.05)$ observed in those older than 65 years $(5)$.

In a retrospective study, a VTE post-discharge rate of 4.8 per 1000 discharges was found within 42 days, following 1877 hospital discharges associated with COVID-19. The post-discharge rate of PE associated with other medical conditions was 3.1 per 1000 discharges within 42 days. The risk of VTE postCOVID-19 discharge was not significantly higher (odds ratio 1.6) compared with the risk of VTE after other acute diseases. This study was limited to those with symptomatic thromboembolic events and possibly underestimated the total burden of post-discharged VTE after COVID-19, as many events are mild or asymptomatic $(21,22)$.

The main characteristic of patients with postdischarge PE was the highly elevated D-dimer values, a five to 200-fold increase above the cut-off level used in different studies. The D-dimer values were significantly increased at the initial COVID-19 hospitalization, being the highest at $\mathrm{PE}$ admission (7, 10-15, 17-20). They had the same pattern in our patients, with values from 10 to 20 times above the upper limit of normal at first admission and even greater at PE diagnostic, with values from 10 to 34 times higher (Table 1). Therefore, when the patients came with acute dyspnea or respiratory distress after an initial clinical improvement or after discharge, extremely high levels of D-dimer (at least five times higher than normal values) suggested late PE development $(6,9-14,19)$. A French retrospective study in 394 COVID-19 patients, proposes a D-dimer cut-off of $2500 \mathrm{ng} / \mathrm{ml}$ (normal range $<400 \mathrm{ng} / \mathrm{ml}$ ) for the PE diagnostic. The study also presented that D-dimer is associated with an increased risk of death (if $>1000$ ) and has an important prognostic role (22). However, a prospective study is required to assess the frequency of late $\mathrm{PE}$ and validate the proposed D-dimer cut-off of $2500 \mathrm{ng} / \mathrm{mL}$ to indicate the presence of PE in COVID-19 patients.

Another characteristic in our case series is a disproportionally elevated D-dimer value in comparison to other coagulation or inflammatory blood parameters (Table 1). This pattern is like other case series reports of post-discharge PE and should, hence, raise suspicion for pulmonary or venous embolism even in the absence of symptomatology $(9,10,11)$.

An important characteristic of most patients was the absence of pre-existing risk factors for VTE and the absence of signs of deep vein thrombosis at VDUS, suggesting that COVID-19 itself - by promoting a prothrombotic status - may be a risk factor $(2,3,22,23)$. 
Apart from a female patient in one study, none were found to have inherited thrombophilia to explain the occurrence of the thromboembolic event (10). In our cases, none of the patients had thromboembolic risk factors, and VDUS were performed on all patients with none found with venous thrombosis. Thus, the probable triggers for thrombotic events are the inflammatory status and diffusing the endothelial damage that predisposes to widespread thrombotic vascular lesions $(2,3)$.

All the patients in our case series during hospitalization had thromboprophylaxis (not full doses) with enoxaparin SC $0.6,0.8$, or $1 \mathrm{ml}$ once daily for seven days. The recommendations of the 2020 - American College of Chest Physicians (ACCP) guideline and expert panel report for the prevention, diagnosis, and treatment of VTE in patients with COVID-19 suggest the current standard dose of anticoagulant (not intermediate) thromboprophylaxis during hospitalization and extended thromboprophylaxis after hospital discharge for those with low risk of bleeding (24). We do not have data for D-dimer values on hospital discharge after COVID-19 treatment and none of the patients had post-discharge oral anticoagulation. This issue could be related to the apparition of late PE. However, until now, no trials were addressing the role and duration of thromboprophylaxis in COVID-19 patients after discharge and no trial evaluating the predictive value of D-dimer for the risk of VTE after anticoagulation withdrawal.

Finally, our patients had a favorable therapeutic evolution to parenteral and oral anticoagulants. Usually, much of the late PE after COVID-19 is segmental or subsegmental, and, therefore, the evolutions are generally good $(9-11,22,23,25)$. The pulmonary angio-CT in our patients showed filling defects of the distal segmental and subsegmental arterial branches (two cases) and left lower pulmonary artery (two cases). Pulmonary inflammation caused by COVID-19 and the absence of signs of venous thrombosis at VDUs suggests a pulmonary thrombosis rather than a PE. In a series of 109 hospitalized COVID-19 patients who had suspicions of PE, the patients with confirmed PE were $41 / 101(40.6 \%)$, while those with deep venous thrombosis at VDUs were $5 / 41(12.2 \%)$. Thus, the authors hypothesized that the thrombosis due to diffuse pulmonary inflammation explained the PE, rather than the thromboembolism. The question could not be solved due to the limited number of available autopsy studies. Additionally, further research is required to clarify the different PE scenarios seen in the current studies (25).

\section{Limitations}

Our series was retrospective with only four patients presented at the hospital with $\mathrm{PE}$ suspicion after the initial COVID-19 discharge. There is no data for the D-dimer values on hospital discharge after the COVID-19 treatment. Therefore, our data should be interpreted cautiously until larger studies bring in more parameters to predict the apparition of late PE in COVID-19 patients.

\section{CONCLUSION}

PE is a complication of the COVID-19 disease which may occur later, especially in young patients with no other risk factors for pulmonary embolus. The highly elevated levels of D-dimer at COVID-19 admission are correlated not only with the prognostic but also with the risk of thromboembolic complications and seem to be associated with the post-discharge apparition of PE. This data suggests the role of extended anticoagulation in selected COVID-19 patients and warrants further investigations addressing the role and duration of thromboprophylaxis in COVID-19 patients after discharge.

\section{Abbreviations}

SARS-CoV-2 - severe acute respiratory syndrome coronavirus 2

COVID-19 - Coronavirus Disease

PE - pulmonary thromboembolism

VTE - venous thromboembolism

CRP - C reactive protein

LDH - lactate dehydrogenase

INR - international normalized ratio

SC - subcutaneous

BMI - body mass index

ECG - electrocardiogram

Bpm - beats per minute

FEU - Fibrinogen equivalent units

BNP - brain natriuretic peptide

$\mathbf{R} \mathbf{R}$ - reference range

CI - confidence interval

\section{Authors' contributions}

Both authors CP and IF were involved in conceptualization, data collection, interpretation of data, writing - original draft, review drafting, and reviewing the submitted manuscript.

Conflict of Interests: The authors declare that there are no conflicts of interest related to this article.

Funding: None

\section{Licensing}




\title{
Sažetak
}

\section{VISOKE VREDNOSTI D-DIMERA I AKUTNA PLUĆNA EMBOLIJA NAKON OTPUSTA IZ BOLNICE KOD MLADIH PACIJENATA SA KOVID-19: SERIJA SLUČAJEVA}

\author{
Calin Pop, ${ }^{1,2}$ Ionuț Ferenț ${ }^{1}$ \\ ${ }^{1}$ Emergency Clinical County Hospital of Baia Mare, Baia Mare, Romania \\ 2 "Vasile Goldis" University, Faculty of Medicine Arad, Arad, Romania
}

This work is licensed under a Creative Commons Attribution 4.0 International (CC BY 4.0) License.

Uvod: Koronavirusna bolest (KOVID-19), izazvana teškim akutnim respiratornim sindromom koronavirusom 2 (SARS-KoV-2), povezana je sa inflamatornim i protrombotičkim stanjem koje povećava rizik od tromboembolijskih događaja. Visok nivo D-dimera povezan je sa težinom bolesti, a akutna plućna embolija (PE) je najčešća trombotička komplikacija.

Materijal i metode: Analizirali smo seriju od četiri slučaja KOVID-19 kod mladih pacijenata (mlađih od 45 godina) koji su razvili PE sa zakašnjenjem od dve do četiri nedelje nakon otpusta iz bolnice.

terapije kod nekih pacijenata sa KOVID-19 i zahtevaju dalja istraživanja.

Ključne reči: D-dimer, COVID-19, mladi pacijenti, plućna embolija, otpust pacijenata.

\section{REFERENCES}

1. Cui S, Chen S, Li X, Liu S, Wang F. Prevalence of venous thromboembolism in patients with severe novel Coronavirus pneumonia. J Thromb Haemost. 2020; 18(6): 1421-4. doi: $10.1111 /$ jth.14830.

2. Connors JM, Levy JH. Thromboinflammation and the hypercoagulability of COVID-19. J Thromb Haemost. 2020; 18(7): 1559-61. doi: 10.1111/jth.14849.

3. Ackermann M, Verleden SE, Kuehnel M, Haverich A, Welte T, Laenger F, et al. Pulmonary vascular endotheliosis, thrombosis, and angiogenesis in COVID-19. N Engl J Med. 2020; 383(2): 120-128. doi: 10.1056/NEJMoa2015432.

4. Zhou F, Yu T, Du R, Fan G, Liu Y, Liu Z, et al. Clinical course, and risk factors for mortality of adult in patients with COVID-19 in Wuhan, China: A retrospective cohort study. Lancet. 2020; 395(10229): 1054-62. doi: 10.1016/S01406736(20)30566-3.

5. Desai R., Gandhi Z., Singh S, Sachdeva S, Manaktala $\mathrm{P}$, Savan $\mathrm{S}$, et al. Prevalence of pulmonary embolism in COVID-19: a pooled analysis. SN Compr Clin Med. 2020: 1-4. doi: 10.1007/s42399-020-00605-5. Epub ahead of print.

6. Vadukul P, Sharma DS, Vincent P. Massive pulmonary embolism following recovery from COVID-19 infection: In-
Rezultati: Ovi pacijenti su imali povišeni D-dimer (najmanje 10 puta od gornje granice normale) pri prijemu i u vreme dijagnostike PE, dok su ostali parametri, koji su uključivali zapaljenje i koagulaciju (C-reaktivni protein - CRP, laktat dehidrogenaza - LDH, fibrinogen, INR) bili normalni. Nije bilo prethodno postojećih faktora rizika za PE i svi pacijenti su bili antikoagulirani sa profilaktičkim srednjim dozama enoksaparina.

Zaključak: PE je komplikacija bolesti KOVID-19 koja se može javiti kasnije, posebno kod mladih pacijenata bez drugih faktora rizika za to stanje. Čini se da su visoko povišeni nivoi D-dimera pri prijemu KOVID-19 povezani sa pojavom PE nakon otpuštanja. Ovi podaci sugerišu ulogu produžene antikoagulantne

flammation, thrombosis, and the role of extended thromboprophylaxis. BMJ Case Rep. 2020; 13(9): e238168. doi: 10.1136/ bcr-2020-238168.

7. Oflar E, Caglar FN. Pulmonary embolism after successful COVID-19 treatment. Int J Cardiovasc Acad. 2020; 6(3): 137-9. doi: 10.4103/IJCA.IJCA_24_20.

8. Di Tano G, Moschini L, Loffi M, Testa S, Danzi GB. Late pulmonary embolism after COVID-19 pneumonia despite adequate rivaroxaban treatment. Eur J Case Rep Intern Med. 2020; 7(7): 001790. doi:10.12890/2020 001790.

9. Karolyi M, Pavelka E, Omid S, Kelani H, Mader T, Baumgartner S, et al. Late-onset pulmonary embolism in young male otherwise healthy COVID-19 patients. Eur J Clin Microbiol Infect Dis. 2021; 40(3): 633-5. doi: 10.1007/s10096-02004044-x. Epub 2020 Sep 23.

10. Vechi HT, Maia LR, Alves MDM. Late acute pulmonary embolism after mild Coronavirus disease 2019 (COVID-19): A case series. Rev Inst Med Trop Sao Paulo. 2020; 62: e63. doi: 10.1590/S1678-9946202062063.

11. Greenan-Barrett J, Perera A. COVID-19 and Pulmonary Emboli: A case series and literature review. Clin Pract Cases Emerg Med. 2020; 4(3): 299-303. doi: 10.5811/cpcem.2020.7.48174.

12. Beckman, M., Nyrén, S, Kistner, A. A case report of widespread pulmonary embolism in a middle-aged male seven weeks after asymptomatic suspected COVID-19 infection. Thrombosis J. 2020; 18: 19. doi: 10.1186/s12959-020-00235-w.

13. Touré A, Donamou J, Camara A, Dramé B, BAH, O. Post-COVID-19 late pulmonary embolism in a young wom- 
an about a case. OJEM. 2020; 8(4): 79-85. doi: 10.4236/ ojem.2020.84009.

14. Koche M, Bechmann S, Omoruyi IS. Bilateral pulmonary embolism in a discharged patient with resolved COVID-19 pneumonia. Cureus. 2020; 12(7): e9406. doi: 10.7759/cureus.9406.

15. Akiyama Y, Horiuchi K, Kondo Y, Kabata H, Ishii M, Fukunaga K. A case of non-severe COVID-19 complicated by pulmonary embolism. Respirol Case Rep. 2020; 8(7): e00622. doi: $10.1002 / \mathrm{rcr} 2.622$.

16. Kanso M, Cardi T, Marzak H, Schatz A, Faucher L, Grunebaum L, et al. Delayed pulmonary embolism after COVID-19 pneumonia: a case report. Eur Heart J Case Rep. 2020; 4(6): 1-4. doi: 10.1093/ehjcr/ytaa449.

17. Vitali C, Minniti A, Caporali R, Del Papa N. Occurrence of pulmonary embolism in a patient with mild clinical expression of COVID-19. Thromb Res. 2020; 192: 21-2. doi: 10.1016/j.thromres.2020.05.002.

18. Bellieni A, Intini E, Taddei E, Baldi F, Larosa L, Murri $\mathrm{R}$, et al.Challenges in COVID-19: Is pulmonary thromboembolism related to overall severity? Infect Dis (Lond). 2020; 52(8): 585-9. doi: 10.1080/23744235.2020.1769854.

19. Tveita A, Hestenes S, Sporastřyl ER, Pettersen SA, Neple BL, Myrstad M, et al. Pulmonary embolism in cases of COVID-19. Tidsskr Nor Laegeforen. 2020; 140: 0526. doi: 10.4045/tidsskr.20.0366.

20. Roberts LN, Whyte MB, GeorgiouL, Giron G, Czuprynska J, Rea C, et al. Postdischarge venous thromboem- bolism following hospital admission with COVID-19. Blood. 2020; 136 (11): 1347-50. doi: 10.1182/blood.2020008086.

21. Mouhat B, Besutti M, Bouiller K, Grillet F, Monnin C, Ecarnot $\mathrm{F}$, et al. Elevated D-dimers and lack of anticoagulation predict PE in severe COVID-19 patients. Eur Respir J. 2020; 56(4): 2001811. doi:10.1183/13993003.01811-2020.

22. Graziani A, Domenicali M, Zanframundo G, Palmese F, Caroli B, Graziani L: Pulmonary artery thrombosis in COVID-19 patients. Pulmonology. 2020:S25310437(20)30185-9. doi: 10.1016/j.pulmoe.2020.07.013. Epub ahead of print

23. Cavagna E, Muratore F, Ferrari F. Pulmonary Thromboembolism in COVID-19: venous thromboembolism or arterial thrombosis? Radiol Cardiothorac Imaging. 2020. 9; 2(4): e200289. doi: 10.1148/ryct.2020200289.

24. Moores LK, Tritschler T, Brosnahan S, Carrier M, Collen JF, Doerschug K, et al. Prevention, diagnosis, and treatment of VTE in patients with coronavirus disease 2019: CHEST Guideline and Expert Panel Report. Chest. 2020; 158(3): 114363. doi: 10.1016/j.chest.2020.05.559.

25. Lax SF, Skok K, Zechner P, Kessler HH, Kaufmann $\mathrm{N}$, Koelblinger $\mathrm{C}$, et al. Pulmonary arterial thrombosis in COVID-19 with fatal outcome: Results from a prospective, single-center, clinicopathologic case series. Ann Intern Med. 2020; 173(5): 350-61. doi: 10.7326/M20-2566.

\section{Correspondence to/Autor za korespondenciju} Călin Pop MD. PhD

Emergency Clinical County Hospital of Baia Mare, "Vasile Goldis" University, Faculty of Medicine Arad Romania.e-mail: medicbm@yahoo.com, tel-0744515794 